\title{
WestVirginiaUniversity.
}

Department of Economics

Working Paper Series

\section{Does the Median Voter or Special Interests Determine State Highway Expenditures? Recent Evidence}

Joshua Hall

Shree Baba Pokharel

Working Paper No. 16-09

This paper can be found at the College of Business and Economics Working Paper Series homepage: 


\title{
Does the Median Voter or Special Interests Determine State Highway Expenditures? Recent Evidence
}

\author{
Joshua Hall \\ Associate Professor of Economics \\ Faculty Affiliate, Regional Research Institute \\ College of Business and Economics \\ 1601 University Drive, PO BOX 6025 \\ West Virginia University \\ Morgantown, WV 26506-6025 \\ joshua.hall@mail.wvu.edu \\ Shree Baba Pokharel \\ Graduate Student \\ College of Business and Economics \\ 1601 University Drive, PO BOX 6025 \\ West Virginia University \\ Morgantown, WV 26506-6025 \\ sbpokharel@mix.wvu.edu
}

\begin{abstract}
Using cross-sectional data from fifty states of the United States and the District of Columbia for two different time periods, this paper examines the degree to which special interests or the median voter determines state highway expenditures. In addition to finding that previous estimates of the determinants of state highway expenditures are robust, we find that that special interests that were important in 1984 were no longer significant nearly 20 years later. Like the previous literature, we conclude that the reduced form median voter model performs well in explaining state highway expenditures.
\end{abstract}

Keywords: median voter model, special interests, highway expenditures

JEL codes: H41, H49, H60, H72, H76 


\section{Introduction}

What determines public sector output? Is it determined by need? The voters? Policymakers? Bureaucrats? The answer likely depends on what public sector output is under consideration. For example, Hall et al. (2015) find while economic variables such as median income explaining the amount of subsidies rural airports receive though the Essential Air Service program, having a member of Congress on the House Transportation or Ways and Means Committee explains a significant portion of the biannual subsidy a rural airport receives. Similarly, Garrett and Sobel (2003) find that nearly half of all Federal Emergency Management Agency (FEMA) spending from 1991 to 1999 was motivated by politics, not relief. In the case of FEMA, the influences were largely in states that were politically important to the President of the United States and in congressional districts where a member of Congress served on the FEMA oversight committee and thus had some influence over the agency. In the wake of Hurricane Katrina, the role that politics played relative to need became even more acute (Congleton 2006; Shughart 2006).

Sobel et al. (2007) updated the analysis of FEMA in the mid-2000s following the post-9/11 merger between FEMA and the Department of Homeland Security. Interestingly, they find that while states that are political important for the President continue to have a higher probability of disaster declaration, Congressional oversight through the committee system no longer explains the amount of disaster declarations. The authors conclude that the merger appeared to have reduced some of the political pressures within FEMA to allocate resources based on politics, not need. In a similar vein, Beaulier et al. (2011) find that traditional political factors such as congressional oversight or importance to the President no longer played a role in military base closures following the passage of the Base Realignment and Closure Act. These papers and other updates of historical political economy models such as Hall et al. (2012) and Sobel and Hall (2016) show both the 
importance of replication (Alm 2010) and how the importance of political economy factors with respect to outcome of collective decision-making can change over time.

In this paper we both replicate and update an important paper in the median voter model literature. Congleton and Bennett (1995) is an extremely important paper in the public choice literature for at least two reasons. First, the paper was the first to explore the determinants of state road expenditures from the perspective of positive economics. Given that the public sector spends billions to build, operate, and maintain highways in the United States this was an important oversight in the literature given that normative public finance suggests that highways might be a good underprovided by the market (Oakland 1972). Second, the paper was the first paper to explicitly incorporate both the median voter model and special interests in the same theoretical and empirical model. It is for that reason that Congleton and Bennett (1995) has garnered a large number of subsequent citations in both the determinants of public highway funding (Goel and Nelson 2003; Gamkhar 2003; Walden and Eryuruk 2012) and the political economy of state policy more generally (Ahmed and Greene 2000; Sutter and Poitras 2002; Hersch et al. 2004).

We begin Section 2 by discussing our replication of Congleton and Bennett (1995). To preview our results, we can replicate their data except for Sierra Club membership by state, which we were not able to obtain for the year of their study. Even missing that variable, our results are quite similar to theirs. In Section 3 we estimate their main empirical specifications (minus Sierra club membership) for 2013. Our findings suggest that the dynamics of state government expenditures have changed considerably in nearly three decades. Nearly all of the variables that were economically and statistically significant in 1984 are no longer significant in 2013 . The only consistently significant variable in 2013 is federal highway aid per mile. Importantly, special interests that were important determinants of funding in 1984 seem to no longer have meaningful 
influence. We conclude in Section 4 with some thoughts on replication and the importance of further testing median voter and special interest theories of collective decision-making.

\section{The Political Economy of State Highway Spending in 1984}

While our exercise is largely an empirical one, Congleton and Bennett (1995) devote a considerable amount of time on the theory behind the political economy of roads. For the median voter, roads are largely a derived demand. Individuals demand roads because they are an input into other goods and services they would like to consume. Under a majority rule for collective decisionmaking, the road network - including highways - reflects the preferences and budget constraint of the median voter. The median voter's demand for roads is going to vary as income, population, federal grants, factor prices, and driving distance change.

In contrast to the median voter model, the pure special interest view of government output is put forth by individuals like Olson (1965) and Becker (1983). The special interest model starts from the obvious point that public policies do not affect all individuals equally. Those who are affected most by a particular policy are like to want to expend resource towards influencing the direction of policy on that issue. As Congleton and Bennett (1995) astutely point out, in many ways the special interest model of public policy is a theory of how the tails of the distribution of public preferences on an issue affect the final outcome. In particular, the influence of special interests is based on their size in both the Olson and Becker models. In a pure special interest model, only special interests matter. From a more general political economy theory, special interests can tilt the outcome away from the median voter's preferred road network depending on the relative size of the pro- and anti-road interest groups in a jurisdiction. 
The existence of three political economy models of public sector demand for roads (pure median voter, pure special interest, and combined) means that the question of which model best reflects reality is an empirical question. Congleton and Bennett (1995) empirically test between the three models using data on state highway expenditures per mile in 1984, arguing that state highway systems are the purest test of their model since state highway expenditures have their own tax base and thus highway spending is a distinct policy choice at the state level. In addition to their dependent variable of total state highway expenditures per mile, they collected a large number of variables to test the three basic models. For example, median income is used as a measure of the median voter's preference for road networks and the average wage of highway construction labor is a factor price that might have an influence on the median voter's demand. Similarly, per capita trucking employment and politically active Sierra Club members per state are two of the measures of special interests they use. For a full description of their data and empirical results and discussion, we refer the reader to Congleton and Bennett (1995) as our discussion here is necessarily much shorter than their detailed explanation of how the variables match up to their theoretical model.

We began our replication and updating of their work by attempting to replicate their data set. One issue we encountered is that their paper does not make clear whether they include the District of Columbia in their analysis or not. They only mention states throughout their analysis but there is no mention of the number of observations in any of their empirical tables. Our prior is that Congleton and Bennett (1995) do not include the District of Columbia. However, our data set with District of Columbia included is a little closer to their descriptive statistics table than one that only included the fifty states. We therefore decided to include the District of Columbia in our summary statistics table and in the all subsequent regressions. Exclusion of the District of Columbia does not quantitatively or qualitatively change any of the results reported here. 
Table 1 presents the descriptive statistics of all dependent and independent variables that we collected from current data sources for the year 1984 in an attempt to replicate Table 1 of Congleton and Bennett (1995). We were able to obtain all the variables used in the original paper with the exception of politically active Sierra Club letter writers by state. They report that data from internal Sierra Club documents and we were not able to obtain similar documentation for either 1984 or 2013. Our Table 1 is very close to their Table 1. For example, Congleton and Bennett report mean total trucking employment by state of 30,880 in 1984 . We find the exact same result. Similarly, our mean population (in thousands) is 4,761 while theirs was 4,753 . While there are some larger differences when we look at the maximum and minimum columns, these are still very close to their numbers and are likely the result of subsequent revisions to the data series. The largest discrepancy between our Table 1 and theirs is in the total state highway expenditures per mile of roadway, where our mean is $\$ 43.30$ and theirs is $\$ 37.36$.

We replicate their Table 2 and Table 3 in our Table 2 and Table 3. Note that we adopt their terminology for variable names in the tables, which is abbreviated slightly from the variable names presented in Table 1. For example, the average wage of highway construction labor becomes the road construction wage rate in the regression tables. Looking at Table 1, there are four specifications. The first two columns represent the pure median voter model, just different specifications. Column 4 represents the pure special interest model and thus includes no median voter variables. Column 3, labeled "Combined" includes both median voter and special interest variables.

A side-by-side comparison of our Table 2 and their Table 2 shows results that are very similar in terms of economic and statistical significance. For example, the price of farm land is positively related to state government road expenditures per mile in a statistically significant 
manner in in both median voter regressions and the combined model in our analysis as well as theirs. Similarly, Congleton and Bennett (1995) do not find the road construction wage rate to be statistically significant in the first median voter specification but negative and statistically significant in the more expanded model and the combined model. We have the exact same result.

The one major difference between our results and theirs is for median income. Median income is positive and statistically significant in all the regressions for which it is included in their Table 2 , but is not statistically significant in any of our models although the estimated coefficients are nearly identical between Congleton and Bennett's results and ours. Since our missing variable (Sierra Club letter writers) only appears in the combined specification, this change is likely due to the slight differences in the dependent variable and median income between our sample and theirs. In terms of explanatory power, their most parsimonious median voter model explains more of the variation $(53.0 \%)$ in state government road expenditures in 1984 than does ours $(49.4 \%)$. This is true across all models with the exception of the special interest model. This is interesting since we cannot include Sierra club letter writers, which Congleton and Bennett find to be negatively related to state government road expenditures in a statistically significant manner. The key economic takeaway, however, is the same one as in Congleton and Bennett, namely that median voter variables seem to be explaining most of the cross-state variation in state road expenditures.

Table 3 replicates Table 3 of Congleton and Bennett (1995). This table measures special interest variables in per capita terms rather than absolute group size. Like Congleton and Bennett, we find that in 1984 only trucking and rail employment per capita in non-right-to-work states is related to state road expenditures in a statistically significant manner. The magnitude of our coefficients for trucking employment per capita in non-right-to-work states are much larger than theirs. In addition, we find per capita employment in trucking and railroads to be statistically 
significant in the combined model, which they do not. Also the road construction wage rate and the price of farm land, which they find to be statistically significant in the combined model, are not significant at the same threshold in our Table 3. Ultimately, our results are largely the same as Congleton and Bennett's (1995), with the exception of the finding of statistical significance for railroad and train employment per capita in non-right-to-work states being statistically significant in both the expanded special interest model and the combined model. We remind the reader that our papers are not directly comparable as we are not able to include Sierra Club letter writers. We also note that we tested for spatial dependence in both the dependent variable and error term as encouraged to by LeSage and Dominguez (2012) and we could find no evidence of spatial dependence that require the use of a spatial econometric approach.

\section{The Political Economy of State Highway Spending in 2013}

The demand of the median voter for road systems is a derived demand, as discussed earlier. In the three decades since 1984, much has changed about American society in a way that might influence median voter demand for road systems and state highways in particular. To give but one example, the rise of the Internet allows individuals to do more shopping online which should reduce their demand for road networks. (While the Post Office and UPS also have to deliver goods using roads and gasoline, their demands may be quite different given economies of scale and distribution networks.) Similarly, the relative power and ability to organize of special interest groups might also have changed due to changes in these industries, such as the greater substitution of capital for labor. In particular, the declining number of railroad employees in the average state would be expected to reduce their political clout, ceteris paribus. 
To see the relative importance of median voter versus special interests factors nearly three decades later, we obtained data on all the variables from our replication in Congleton and Bennett (1995) for the year 2013 (or the closest year available). Again, we obtained data for all fifty states and the District of Columbia in order to be as comparable as possible to our results from Table 3, the per capita special interest models. We choose Table 3 as those specifications explained the greatest variation in state government expenditures on roads per mile. Given the similarity of results between the pure special interest model and the more expansive special interest model, we only present three specifications: median voter, expanded special interest, and combined. Following Congleton and Bennett (1995) we estimate our model using OLS and the results are presented in Table 4.

Our results are very similar to Congleton and Bennett's in that the median voter model continues to perform well. In the pure median voter model, federal aid per highway mile and the price of farm land continues to be statistically significant. In the expanded special interest model, only federal highway aid per mile is statistically significant and the trucking and railroad per capita variables are not statistically significant. When the median voter model and the special interest model are combined, all variables except for federal highway aid per mile are statistically insignificant. This result is identical to the findings of Congleton and Bennett for 1984, with the exception that they found that the road construction wage rate was negatively related to state government road expenditures at the ten percent level. While the sign on the 2013 road construction wage rate is negative in the combined model in our Table 4, it is statistically insignificant at current levels.

An additional important thing to note is the difference in model fit between 1984 and 2013. In 1984, our combined model presented in Table 3 explained $93.4 \%$ of the variation in state 
government road expenditures per state administered road mile. The same specification in 2013 only explained $56.5 \%$ of the variation. Even the explanatory power of the pure median voter has declined from $84.9 \%$ in 1984 to $53.0 \%$ in 2013 . This suggests that the factors, especially the special interest variables, explaining the cross-state variation in state government road expenditures might have changed considerably over the years. While the exact changes are beyond the scope of our paper, we feel that this highlights the importance of replicating and updating classical political economy papers. The interest groups that were important and powerful at one time might not be as powerful a century later due to technological change, demographic shifts, or any number of reasons.

\section{Conclusion}

Given the importance of highways in the United States, the positive political economy of the level of state government highway expenditures continues to be an important topic. In this paper we make two contributions to the literature on the political economy of road funding and political economy models more generally. First, we replicate the key features of the seminal political economy of highway expenditures paper by Congleton and Bennett (1995). While we find some minor differences, most notably the greater importance of some special interests in some specifications, our differences can largely be explained by slightly different data and our inability to obtain data for Sierra Club letter writers by state. Second, we estimate their political economy model on 2013 data and find very similar results. In 2013, the primary driver of state government expenditures is federal highway aid per mile. We fail to find evidence of railroad or trucking interests playing a role in the determination of state highway spending. 
Our findings highlight the importance of replication in political economy and public finance more generally, as argued by Alm (2010). From a public policy standpoint, they suggest that other special interests might now be more powerful in determining state government road expenditures. Future research should explore what these special interests might be as well as obtain more years of data to explore the dynamics of state funding over a longer time frame. 
Table 1 Descriptive Statistics, 1984 Sample

\begin{tabular}{lrrrr}
\hline \multicolumn{1}{c}{ Variable } & \multicolumn{1}{c}{ Mean } & \multicolumn{1}{c}{ St. Dev. } & \multicolumn{1}{c}{ Min } & \multicolumn{1}{c}{ Max } \\
\hline Total State Highway Expenditures/Mile & $\$ 43.30$ & $\$ 38.25$ & $\$ 8.20$ & $\$ 238.87$ \\
State Area (square miles) & 70,725 & 85,804 & 1,045 & 570,373 \\
Median Income & $\$ 23,017$ & $\$ 3,847$ & $\$ 15,983$ & $\$ 34,782$ \\
Average Value of Farm Land & $\$ 1,079$ & $\$ 657$ & $\$ 177$ & $\$ 3,155$ \\
Average Wage of Highway & & & & \\
Construction Labor & $\$ 442$ & $\$ 128$ & $\$ 277$ & $\$ 1,086$ \\
Federal Highway Administration & & & & \\
Grants per mile & $\$ 19.29$ & $\$ 14.23$ & $\$ 3.09$ & $\$ 71.47$ \\
State Population & 4,761 & 5,069 & 509 & 26,365 \\
Trucking Employment & 30,880 & 31,488 & 1,827 & 149,447 \\
Railroad Employment & 11,529 & 11,292 & 65 & 50,865 \\
Per Capita Trucking Employment & 6.47 & 1.50 & 3.23 & 9.01 \\
Per Capita Railroad Employment & 2.90 & 2.12 & 0.06 & 10.84 \\
Trucking Employment in Non-Right- & & & & \\
to-Work States & 37,244 & 37,742 & 1,827 & 149,447 \\
Railroad Employment in Non-Right-to- & & & & \\
Work States & 137,013 & 13,681 & 65 & 50,865 \\
Per Capita Trucking Employment in & & & & \\
Non-Right-to-Work States & 6.24 & 1.55 & 3.23 & 9.08 \\
Per Capita Railroad Employment in & & & & \\
Non-Right-to-Work States & 2.55 & 1.66 & 0.06 & 8.55 \\
\hline
\end{tabular}

Note: All data is for the 50 states and District of Columbia in 1984. Data sources are the same federal agencies as described in Congleton and Bennett (1995). Retrieved from electronic databases which may have been updated since Congleton and Bennett's study, thus the slight discrepancies in some data between our table above and theirs. 
Table 2 State government road expenditures per state administered road mile in 1984

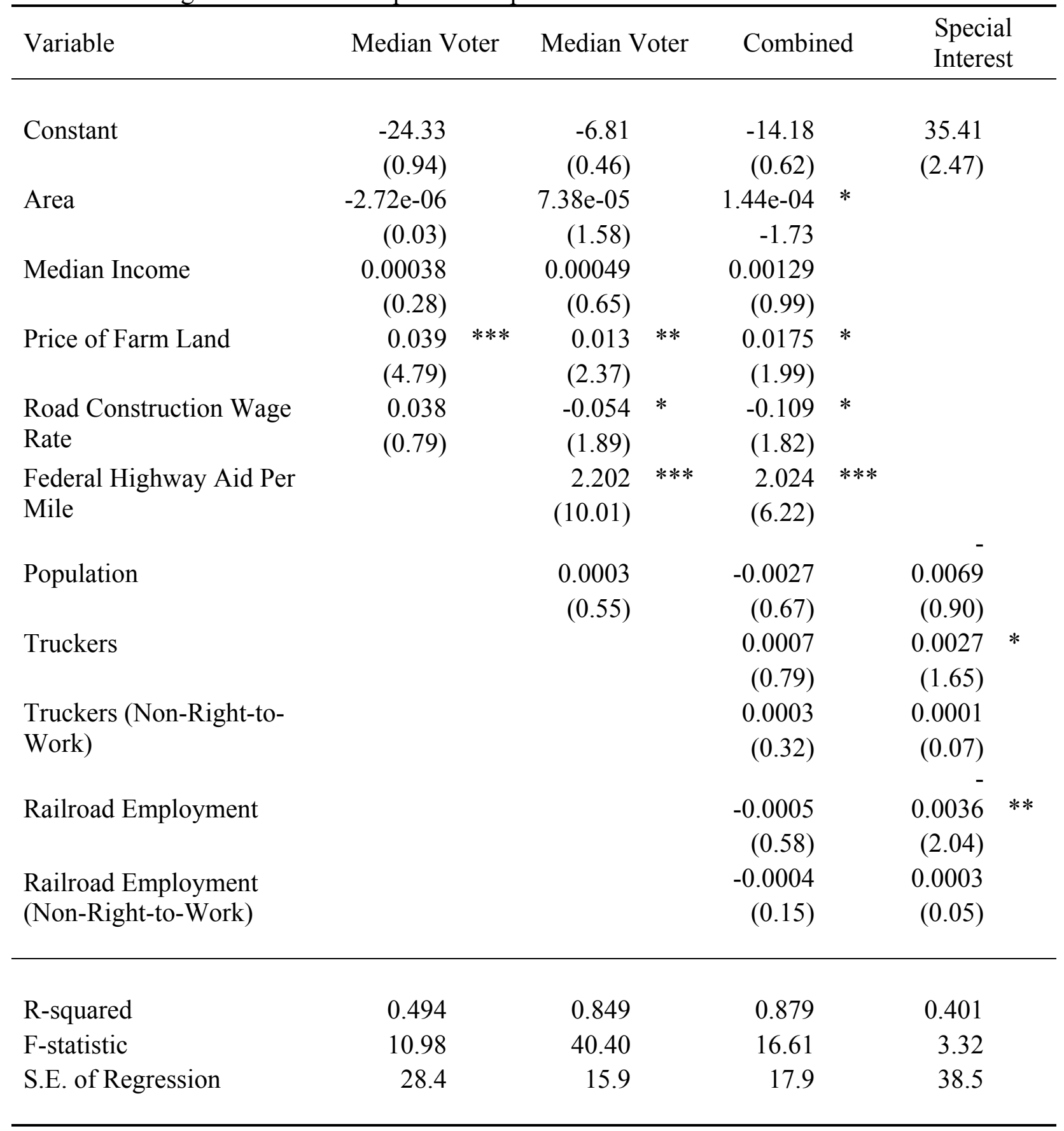

Note: $\mathrm{N}=51$ in all specifications. Numbers in parentheses are absolute value of t-statistics. * indicates significance at $10 \%$ level, $* *$ at $5 \%$ level, and $* * *$ significance at $1 \%$ level. 
Table 3 State government road expenditures per state administered road mile in 1984 (Alternate specifications of special interest group size)

\begin{tabular}{|c|c|c|c|c|c|c|c|c|}
\hline Variable & \multicolumn{2}{|c|}{ Median Voter } & \multicolumn{2}{|c|}{ Combined } & \multicolumn{2}{|c|}{$\begin{array}{l}\text { Special } \\
\text { Interest }\end{array}$} & \multicolumn{2}{|c|}{$\begin{array}{l}\text { Special } \\
\text { Interest }\end{array}$} \\
\hline Constant & $\begin{array}{l}-6.82 \\
(0.46)\end{array}$ & & $\begin{array}{l}59.56 \\
(1.66)\end{array}$ & $*$ & $\begin{array}{r}175.11 \\
(3.47)\end{array}$ & $* * *$ & $\begin{array}{l}65.99 \\
(2.49)\end{array}$ & $* *$ \\
\hline Area & $\begin{array}{r}7.38 \mathrm{e}-05 \\
(1.58)\end{array}$ & & $\begin{array}{r}4.32 \mathrm{e}-05 \\
(0.58)\end{array}$ & & & & & \\
\hline Median Income & $\begin{array}{r}0.00048 \\
(0.65)\end{array}$ & & $\begin{array}{r}0.00107 \\
(1.23)\end{array}$ & & & & & \\
\hline Price of Farm Land & $\begin{array}{r}0.0131 \\
(2.37)\end{array}$ & $* *$ & $\begin{array}{r}0.0086 \\
(1.20)\end{array}$ & & & & & \\
\hline $\begin{array}{l}\text { Road Construction Wage } \\
\text { Rate }\end{array}$ & $\begin{array}{r}-0.0549 \\
(1.89)\end{array}$ & $*$ & $\begin{array}{r}-0.0631 \\
(1.46)\end{array}$ & & & & & \\
\hline $\begin{array}{l}\text { Federal Highway Aid Per } \\
\text { Mile }\end{array}$ & $\begin{array}{r}2.202 \\
(10.01)\end{array}$ & $* * *$ & $\begin{array}{l}1.749 \\
(6.38)\end{array}$ & $* * *$ & & & $\begin{array}{r}1.87 \\
(8.37)\end{array}$ & $* * *$ \\
\hline Population & $\begin{array}{r}0.0003 \\
(0.55)\end{array}$ & & $\begin{array}{r}0.0008 \\
(1.34)\end{array}$ & & & & $\begin{array}{r}0.0010 \\
(1.62)\end{array}$ & $* * *$ \\
\hline $\begin{array}{l}\text { Trucking Employment (per } \\
\text { capita) }\end{array}$ & & & $\begin{array}{r}-0.835 \\
(0.31)\end{array}$ & & $\begin{array}{l}-1.11 \\
(0.22)\end{array}$ & & $\begin{array}{l}0.458 \\
(0.18)\end{array}$ & \\
\hline $\begin{array}{l}\text { Trucking Employment PC } \\
\text { (Non-Right-to-Work) }\end{array}$ & & & $\begin{array}{r}17.5 \\
(2.98)\end{array}$ & $* * *$ & $\begin{array}{l}32.78 \\
(3.33)\end{array}$ & $* * *$ & $\begin{array}{l}18.81 \\
(3.87)\end{array}$ & $* * *$ \\
\hline $\begin{array}{l}\text { Railroad Employment (per } \\
\text { capita) }\end{array}$ & & & $\begin{array}{l}0.372 \\
(0.20)\end{array}$ & & $\begin{array}{r}5.65 \\
(1.58)\end{array}$ & & $\begin{array}{r}1.392 \\
(0.79)\end{array}$ & \\
\hline $\begin{array}{l}\text { Railroad Employment PC } \\
\text { (Non-Right-to-Work) }\end{array}$ & & & $\begin{array}{l}-21.62 \\
(3.87)\end{array}$ & $* * *$ & $\begin{array}{r}-41.43 \\
(4.41)\end{array}$ & $* * *$ & $\begin{array}{r}-22.78 \\
(4.62)\end{array}$ & $* * *$ \\
\hline $\begin{array}{l}\text { R-squared } \\
\text { F-statistic }\end{array}$ & $\begin{array}{r}0.849 \\
40.4\end{array}$ & & $\begin{array}{l}0.934 \\
26.96\end{array}$ & & $\begin{array}{r}0.571 \\
8.32\end{array}$ & & $\begin{array}{l}0.913 \\
4055\end{array}$ & \\
\hline
\end{tabular}

Note: $\mathrm{N}=51$ in all specifications. Numbers in parentheses are absolute value of t-statistics. * indicates significance at $10 \%$ level, $* *$ at $5 \%$ level, and $* * *$ significance at $1 \%$ level. 
Table 4 State government road expenditures per state administered road mile in 2013 (Alternate specifications of special interest group size)

\begin{tabular}{|c|c|c|c|c|}
\hline Variable & Median Voter & Combined & Special Int & erest \\
\hline Constant & $\begin{array}{r}-58.21 \\
(0.39)\end{array}$ & $\begin{array}{r}-138.07 \\
(0.80)\end{array}$ & $\begin{array}{r}-197.50 \\
(1.96)\end{array}$ & $*$ \\
\hline Area & $\begin{array}{r}0.00015 \\
(0.48)\end{array}$ & $\begin{array}{r}0.00021 \\
(0.35)\end{array}$ & & \\
\hline Median Income & $\begin{array}{r}-9.48 \mathrm{e}-06 \\
(0.00)\end{array}$ & $\begin{array}{r}-0.00107 \\
(0.35)\end{array}$ & & \\
\hline Price of Farm Land & $\begin{array}{l}0.189 * \\
(1.73)\end{array}$ & $\begin{array}{r}0.0155 \\
(1.38)\end{array}$ & & \\
\hline $\begin{array}{l}\text { Road Construction Wage } \\
\text { Rate }\end{array}$ & $\begin{array}{r}-0.0209 \\
(0.71)\end{array}$ & $\begin{array}{r}-0.0315 \\
(0.93)\end{array}$ & & \\
\hline $\begin{array}{l}\text { Federal Highway Aid Per } \\
\text { Mile }\end{array}$ & $\begin{array}{r}2.25 * * * \\
(3.91)\end{array}$ & $\begin{array}{r}2.71 * * * \\
(4.31)\end{array}$ & $\begin{array}{r}3.04 \\
(6.68)\end{array}$ & $* * *$ \\
\hline Population & $\begin{array}{r}3.14 \mathrm{e}-06 \\
(0.89)\end{array}$ & $\begin{array}{r}3.94 \mathrm{e} 06 \\
(0.84)\end{array}$ & $\begin{array}{r}3.30 \mathrm{e}-06 \\
(0.93)\end{array}$ & \\
\hline $\begin{array}{l}\text { Trucking Employment (per } \\
\text { capita) }\end{array}$ & & $\begin{array}{r}117.34 \\
(1.37)\end{array}$ & $\begin{array}{l}92.26 \\
(1.19)\end{array}$ & \\
\hline $\begin{array}{l}\text { Trucking Employment PC } \\
\text { (Non-Right-to-Work) }\end{array}$ & & $\begin{array}{r}44.39 \\
(0.44)\end{array}$ & $\begin{array}{l}38.91 \\
(0.44)\end{array}$ & \\
\hline $\begin{array}{l}\text { Railroad Employment } \\
\text { (per capita) }\end{array}$ & & $\begin{array}{r}-146.17 \\
(0.13)\end{array}$ & $\begin{array}{r}311.25 \\
(0.29)\end{array}$ & \\
\hline $\begin{array}{l}\text { Railroad Employment PC } \\
\text { (Non-Right-to-Work) }\end{array}$ & & $\begin{array}{r}2008.23 \\
(0.97)\end{array}$ & $\begin{array}{r}2060.86 \\
(1.06)\end{array}$ & \\
\hline $\begin{array}{l}\text { R-squared } \\
\text { F-statistic }\end{array}$ & $\begin{array}{r}0.530 \\
861\end{array}$ & $\begin{array}{r}0.565 \\
520\end{array}$ & $\begin{array}{r}0.563 \\
576\end{array}$ & \\
\hline
\end{tabular}

Note: $\mathrm{N}=51$ in all specifications. Numbers in parentheses are absolute value of $\mathrm{t}-$ statistics. * indicates significance at $10 \%$ level, ** at $5 \%$ level, and *** significance at $1 \%$ level. 


\section{References}

Ahmed, S., \& Greene, K. V. (2000). Is the median voter a clear-cut winner? Comparing the median voter theory and competing theories in explaining local government spending. Public Choice, 105, 207-230.

Alm, J. (2010). A call for replication studies. Public Finance Review, 38, 139-145.

Beaulier, S. A., Hall, J. C., \& Lynch, A. K. (2011). The impact of political factors on military base closures. Journal of Economic Policy Reform, 14, 333-342.

Becker, G. (1983). A theory of competition among pressure groups for political influence. Quarterly Journal of Economics, 98, 371-400.

Congleton, R. D., \& Bennett R. W. (1995). On the political economy of state highway expenditures: Some evidence of the relative performance of alternative public choice models. Public Choice 84, 1-24.

Congleton, R. D. (2006). The story of Katrina: New Orleans and the political economy of catastrophe. Public Choice, 127, 5-30.

Gamkhar, S. (2003). The role of federal budget and trust fund institutions in measuring the effect of federal highway grants on state and local government highway expenditure. Public Budgeting \& Finance, 23, 1-21.

Garrett, T. A., \& Sobel, R. S. (2003). The political economy of FEMA disaster payments. Economic Inquiry, 41, 496-509.

Goel, R. K., \& Nelson, M. A. (2003). Use or abuse of highway tax revenues? An economic analysis of highway spending. Applied Economics Letters, 10, 813-819.

Hall, J. C., \& Schiefelbein, J. (2011). The political economy of medical marijuana laws. Atlantic Economic Journal, 39, 197-198. 
Hall, J. C., Nesbit, T. M., \& Thorson, R. (2012). The determinants of congressional franking: Evidence from the 110th congress. Journal of Applied Economics \& Policy, 31, 25-34.

Hall, J., Ross, A., \& Yencha, C. (2015). The political economy of the Essential Air Service program. Public Choice, 165, 147-164.

Hersch, J., Rossi, A. F. D., \& Viscusi, W. K. (2004). Voter preferences and state regulation of smoking. Economic Inquiry, 42, 455-468.

LeSage, J. P., \& Dominguez, M. (2012). The importance of modeling spatial spillovers in public choice analysis. Public Choice, 150, 525-545.

Oakland, W. H. (1972). Congestion, public goods and welfare. Journal of Public Economics, 1, $339-357$.

Olson, M. (1965). Logic of Collective Action. Cambridge: Harvard University Press.

Peterson, G. E. (1986). Urban road reinvestment: The effects of external aid. American Economic Review 76, 159-164.

Shughart II, W. F. (2006). Katrinanomics: The politics and economics of disaster relief. Public Choice, 127, 31-53.

Sobel, R. S., Coyne, C. J., \& Leeson, P. T. (2007). The political economy of FEMA: Did reorganization matter? Journal of Public Finance and Public Choice, 25, 151-167.

Sobel, R.S., \& Hall, J.C. (2016). Has the war between the rent seekers escalated? Cato Journal, $36,47-53$.

Sutter, D., \& Poitras, M. (2002). The political economy of automobile safety inspections. Public Choice, 113, 367-387.

Walden, M. L., \& Eryuruk, G. (2012). Determinants of local highway spending in North Carolina. Growth and Change, 43, 462-481. 